\title{
Soil Disturbance under small harvester traffic in paddy-based smallholder farms in China
}

\author{
by Huo, L.F., Liang, L., Abbas, A., White, D., Ding, Q.S., \\ Wang, X.C., He, R.Y. and Sun, Q.
}

Copyright, publisher and additional information: this is the author accepted manuscript. The final published version (version of record) is available online via Wiley. This article may be used for non-commercial purposes in accordance with Wiley Terms and Conditions for Self-Archiving.

Please refer to any applicable terms of use of the publisher.

DOI: https://doi.org/10.1002/ps.5545

\section{Harper Adams University}




\section{Soil Disturbance under Small Harvester Traffic in Paddy-based Smallholder Farms in China}

Lian Fei Huo, Lei Liang, Adnan Abbas, David White, Qi Shuo Ding, ${ }^{*}$ Xiao Chan Wang, Rui Yin He, and Qian Sun

L.F. Huo, L. Liang, A. Abbas, Q.S. Ding, X.C. Wang, and R.Y. He, Key Lab. of Intelligent Agricultural Equipment of Jiangsu Province, College of Engineering, Nanjing Agricultural Univ., Nanjing 210031, China; D. White, Engineering Department, Harper Adams Univ., Edgmond, Newport TF108NB, UK; and Q, Sun, Key Lab. for Protected Agricultural Engineering in the Middle and Lower Reaches of Yangtze River, Institute of Agricultural Facilities and Equipment, Jiangsu Academy of Agricultural Sciences, Nanjing 210031, China. *Corresponding author (qsding@njau.edu.cn).

Abbreviations: 2WT, two-wheel tractors; CTF, controlled traffic farming; SFSE, smallholder farms using small equipment.

\footnotetext{
ABSTRACT

Machine-induced soil disturbance may negatively impact the sustainability of a smallholder farming system. On-farm studies at 143 fields were conducted over 3 crop seasons with the goal of quantifying the effect of soil disturbance on rice paddy productivity induced by small harvesters (i.e.

This article has been accepted for publication and undergone full peer review but has not been through the copyediting, typesetting, pagination and proofreading process, which may lead to differences between this version and the Version of Record. Please cite this article as doi: 10.1002/agj2.20134.
}

This article is protected by copyright. All rights reserved. 
power $<75 \mathrm{~kW}$, weight $<3.5 \mathrm{Mg}$ and working width $<2,200 \mathrm{~mm}$ ). A field survey toolbox containing fine-layered cone penetration test, soil micro-relief measurement, soil physics test (water content, bulk density and porosity), documentation of field attributes, harvesters' technical specifications, cropping systems and farmers' practices was used for field observation. Results showed that harvester traffic increased soil bulk density and decreased soil porosity. However, harvester-induced soil changes in statistics were not detected. In addition, trafficked lanes had great soil strength $(P=0.05)$ than non-trafficked lanes, and equipment induced compaction was limited to the surface $150 \mathrm{~mm}$. Therefore, small harvesters minimized subsurface soil damage. However, regardless of the model and specification, all harvesters caused ruts. Small field sizes, irregular field shapes, inconsistent field management practices, lacking soil protection awareness, excessive soil water content during rice harvesting and random field traffic were identified as major factors aggravating soil disturbance. Above these, several well-established approaches to alleviate machine-induced soil damage were also observed during the field survey, including pre-harvesting drainage, floating chassis, ultra-narrow wheels and puddling.

Core ideas

The increase of soil strength induced by small harvesters was limited to the surface $150 \mathrm{~mm}$.

Soil micro-relief was more severely damaged by rice harvesting than wheat harvesting.

Soil damage was associated with the use of small machines. 
Pre-harvesting drainage, floating chassis, ultra-narrow wheels and puddling alleviated soil damage.

\section{INTRODUCTION}

To reduce labor shortages, many small farms in China are managed with mechanized harvesting and planting. However, mechanization increases the risk of compaction, soil degradation, and possible yield losses (Lipiec and Hatano, 2003).

A large percent of the prior compaction research was conducted on large farms using big equipment (Chamen et al., 2006; Botta et al., 2006). To date, little information is available for smallholder farms using small equipment (SFSE). Furthermore, majority of the results discussed the impact of the tractor loading process on soil stress-strain interactions (Håkansson and Reeder, 1994; Gysi et al., 2001; Hamza and Anderson, 2005; Zink et al., 2011; Chamen et al., 2015). There is a scarcity of information on how and to what extent traffic-induced soil disturbance could be governed by the attributes of a farming system (e.g., soil types, geo-meteorological conditions, cropping systems, machine types and technical specifications, field sizes, etc.). Lack of such information places farmers switching from manual to mechanized farming at a tipping point of sustainability. Considering that $85 \%$ of the world's 500 million farms are managed by smallholders (Sims and Kienzle, 2017), this is an important issue.

The impact of small machinery traffic on soil has been addressed by a few authors, but mainly within the context of soil compaction. Håkansson and Reeder (1994) found that repeated 
light-weight vehicular traffic could result in subsoil compaction. Botta et al. (2006) also revealed that, after 10 to 12 times of overlaid passages using a small tractor, soil profile up to $600 \mathrm{~mm}$ depth was severely compacted. In contrast, Johansen et al. (2012) stated that the small and light-weight two-wheel tractors (2WT) adapted for one-pass seeding and fertilizing provided opportunities for conservative farming, especially in resource-poor areas. Due to the light-weight and limited axial load, small machinery traffic resulted in the least amount of soil disturbance and required minimum fuel consumption. Low-cost seed drills powered by 2WT provided an option for conservation agriculture in Asia and Africa (Haque et al., 2016). Despite its low field capacity, small machinery was often accredited with its suitability for smallholder farms. However, all these statements need to be evaluated with field-collected data and verified in different SFSE scenarios.

Smallholder farming in East China is increasingly becoming mechanized. Intensification of the farming system extensively promoted land output, with reported annual yield of rice and wheat up to $18 \mathrm{Mg} \mathrm{ha}^{-1}$ (Ding et al., 2016). However, the temperate and humid climate, insufficient annual heat and radiation for rotating the double crops pose greater challenges for the local smallholders. One particular aspect is the need for intensified mechanization for field operations, which has also been alleged as a major cause of degradation on the sustainability of farming lands. Therefore, the goal of this research was to quantify the effect of harvester-induced disturbance on rice paddy productivity in SFSE scenario. 


\section{MATERIALS AND METHODS}

On-farm studies were conducted at 143 fields and 4 commercial farms in the autumn rice harvesting in 2016 and the summer wheat and autumn rice harvesting in 2017. The area investigated (Luhe, Nanjing) was located in East China, a coastal, leveled but fragmented landscape historically managed by smallholders in rice-wheat rotation. The climate regime was subtropical monsoon, with an average annual precipitation of $1048.6 \mathrm{~mm}$ and an average annual temperature of $15.8^{\circ} \mathrm{C}$. Soil textures of the region ranged from sandy loam to clay loam. The fields were characterized for changes in soil penetration resistance, soil micro-relief, soil water content and soil bulk density , all of which were measured both prior to and post harvesting. The paddy season begins in June and ends up by late November, after which wheat season ensued.

As the aim of the investigation was to illustrate the real field-occurring processes, precaution was taken to avoid any researcher-induced interferences with local farming practices. The team randomly scouted the countryside during crop harvesting season. When crop harvesting was seen on-going, the team gained access to the field and recorded data, which include field size, cropping pattern, harvester specifications (power, weight, working width and track/wheel width) and farmers' field operational habits (e.g. fieldwork pattern, crop and field management practices) (Wang, 2018).

Field size was measured with a $100 \mathrm{~m}$ tape measure. Harvester's technical specifications were registered and field working patterns were manually recorded. Soil was sampled randomly during field survey. Paired soil samples were taken (one from the center of track lanes and another $0.5 \mathrm{~m}$ 
sideway from trafficked lines apparently free from soil disturbance). Soil cores (50 mm×50 $\mathrm{mm}$ in height and diameter) were collected from 0-50, 50-100 and 100-150 mm depths, respectively, and sealed in plastic bags and transported to the laboratory for soil physical analysis. After the trial test on this field survey method in the first crop harvesting season, the collected data was analyzed revealing a need to clarify whether the sampled soil depths (3-layer sampling to $150 \mathrm{~mm}$ depth) were sufficient. In the second harvesting season the soil was sampled for 4 depths (i.e. 0-50, 50-100, 100-150 and 150-200 mm), and the result showed a good agreement with that acquired in the first season. Thus in the third season the soil was again sampled to 3 layers, simply for consideration of reduced field workload and in accord with common practice of field studies.

Soil water content within the tilled soil layer was monitored on-site with KZTakeme-10 moisture meter (K.LUN-ZHONDA Co. Ltd.). Soil bulk density was determined from weight of the oven-dried soil $\left(105^{\circ} \mathrm{C}\right.$ for $24 \mathrm{~h}$ ) and total volume of the soil cores (Zhou et al., 2017). Soil porosity was estimated from bulk density and assumed particle density, i.e. $2.65 \mathrm{~g} \mathrm{~cm}^{-3}$ (Grossman and Reinsch, 2002; Williams et al., 2017). Soil strength of both trafficked and non-trafficked sites was measured with a digital cone penetrometer (TJSD-750, Zhejiang Top Instrument Co. Ltd, China). The penetrometer was specifically designed for layered measuring in each $25 \mathrm{~mm}$, allowing a layer-by-layer comparison of soil strength data. A pin-profilometer was used to monitor soil sinkage underneath traffic lanes. The profilometer was an upgraded version from Botta et al. (2006), which had 100 pins of $1 \mathrm{~m}$ long and provided a $1 \mathrm{~m}$ width effective measurement of soil micro-relief. 
For illustrative purposes, four large commercial farms using big harvesters (i.e., Huanghai, Dafeng, Chongming and Hongzehu Farms) were also investigated within the same agro-ecological zone. Data collection on these large farms only concerned field size and machine technical specifications. This elementary data was used for only illustrative purposes, allowing the SFSE scenario to be explained with technically comparisons. Sufficient reports on soil responses to big machinery traffic can be found elsewhere (Chamen et al., 2006; Botta et al., 2006).

Due to both the short turnover time windows between the two crops and the tedious and time-consuming nature of the field survey, only parts of the surveyed fields were sampled for soil analysis. Considering the large variation of attributes(e.g. geology, irrigation scheme, farming convention, etc.) of smallholder farms either within or amid fields, the collected data were pooled to quantify how the farming system's attributes (i.e. crop season, harvester traffic, soil layer, etc.) impact harvester-induced soil disturbance.

Analysis of variance was made to evaluate the effects of soil depth and harvester traffic on soil water content, soil bulk density, soil porosity and soil strength. Differences between means were determined with Fisher's least significant difference test $(P=0.05)$. The statistical analysis software SPSS (version 19.0, SPSS Inc., Chicago, IL, USA) was used for the statistical analysis. 


\section{RESULTS AND DISCUSSION}

\section{Field status and harvester specifications in the SFSE scenario}

Within the surveyed region, the majority of fields were found to be less than 0.2 ha in size(Fig.1a). This result was similar to that found by Tan et al. (2008) in Jiangxi province, where featured landscape was hilly and mountainous terraces. The similarity of field sizes between the two regions indicated the stability of paddy-based SFSE scenario and the unaffected attributes of smallholder farms, regardless of differed landscapes, ever-increasing rural economy, improved farming technologies and management practices.

Field size has been frequently used as a criterion to assess land output and technical efficiency. Large-size farms have been strongly recommended for the replacement of smaller ones. In Sweden, average field size in Svalöv was 6.7 ha (Nilsson et al., 2014). Field in Finland was found as large as 92 ha, with typical field sizes ranged from 20 to 30 ha (Oksanen, 2013). In France, despite the mean field size of 4.35 ha, such landscape was still described as severely fragmented (Latruffe and Piet, 2014). Spanish fields were in the range of 0.5 to 4 ha (Amiama et al., 2008), while the Germany fields were assumed to be 20 ha (Hülsbergen et al., 2002). Studies also showed that land fragmentation and irregular field shapes could restrict productivity and decrease field efficiency of machinery operations (Tan et al., 2008; Amiama et al., 2008; Latruffe and Piet, 2014).

Paddy farming systems generally require reduced field size for ease of land leveling and puddling, quick irrigation and drainage, which was commonly assumed as precision management in 
local. However, our field observation from large commercial farms indicated that fields could also be managed effectively with big machines under well-constructed infrastructure of irrigation and drainage. Field sizes managed in large farms were greater than 2.5 ha (Fig.1b), which was 10 times larger than those of small farms. Co-existence of the two contrasting farming systems within the same agro-ecological zone also means that large farms using big equipment could readily be adopted to replace the SFSE scenario for scaling up the farm size for higher profit, for improved field capacity and higher resource efficiency by managing the soil and crops in large field sizes.

Four models of small harvesters were observed during field survey, including one Japan model (Kubota PRO688Q), one Korean model (Yanmar YH880) and two Chinese models (World 4LZ04.0A and RG50 4LZ-5G) (Table 1). All these harvesters were tracked, with low power output ( $<75 \mathrm{~kW}$ ), small working width $(<2,200 \mathrm{~mm})$ and light in weight $(<3.5 \mathrm{Mg})$ with low contact pressures $(20-80$ $\mathrm{kPa})$. The only one negative characteristic of small harvesters is their higher soil compaction area ratio (0.4-0.5). Small machines also increase the number of passes in field operation (Zhang et al., 2006).

In contrast with SFSE scenario, large commercial farms using big harvesters had a much higher axial load and tire inflation pressure (Table 1). The 3 models used (John Deere C120, a product of USA; Mushen 4LZ-8, a Chinese model; and Case 4077, a model from Germany) were found to have larger engine power (>120 kW), much heavier weight and a larger cutting bar width. Axle loads and/or tire inflation pressures of these large harvesters were comparable with those reported in the This article is protected by copyright. All rights reserved. 
literature, e.g. $>6.3 \mathrm{Mg}$ wheel load (Zink et al., 2011), $10 \mathrm{Mg}$ axle load (Radford et al., 2000), $5 \mathrm{Mg}$ wheel load and 250-300 kPa tire inflation pressure (Håkansson and Reeder, 1994), 11 Mg tractor with tire pressure of $180 \mathrm{kPa}$ (Gregory et al., 2007).

Although the collected data from the surveyed region allowed us to briefly distinguish the SFSE scenario from large farms using big equipment, the threshold criteria separating the two scenarios were not available. In general sense, small machines are more economically viable for operating in small fields, terraced landforms, and flooded paddy soils. Mechanization using small machines could be sustainable for smallholding agriculture (Johansen et al., 2012; Haque et al., 2016). Søgaard and Sørensen (2004) stated that a good interrelationship between machinery system and biological and meteorological subsystems, such as crop, soil and weather conditions on soil compaction is important.

Although our field survey distinguished differences of farming system's attributes between SFSE scenario and those of large farms using big equipment, this distinction were arbitrary and subjective in related report. Mehta et al. (2011) stated that machinery selection for smallholding farms should depend on the locally available tractor models. Dash and Sirohi (2008) recommended that $11.76 \mathrm{~kW}$ small tractor was suitable for 1 ha soil cultivation, while the highest and market available $44.12 \mathrm{~kW}$ tractor could satisfy the needs of farms in size of 17 to 20 ha. More recently, Zhang et al. (2017) stated that $<75 \mathrm{~kW}$ tractors attaching implements of less than $2 \mathrm{~m}$ working width were generally suitable for less-developed agriculture. 
Similarly, definition on a 'small field' is also subjective, depending on where the field is located (Nilsson et al., 2014). Esengun et al. (2007) treated those field sizes below 1 ha as small farms. Sims et al. (2009) preferred to use 2 ha as a threshold criterion. In addition, the land use method may also affect the definition. For instance, in Iran's smallholding barberry production systems, higher land output and energy efficiency were found on small farms as compared with larger ones (>1 ha) (Mousavi-Avval et al., 2012). In Bulgaria, land fragmentation (average field size of 1.1 ha) negatively affected grain production efficiency (Falco et al, 2010). Field size can be smaller in paddy-based farming areas, e.g. 0.675 ha in Malaysia (Muazu et al., 2015) and 0.1 ha in Jiangxi, China (Tan et al., 2008). Even in highly mechanized areas in Korea, typical field sizes were below 1 ha (Chung et al., 2008). Field size affects technical efficiency of the farming system (Tan et al., 2008). Although general consensus was absent, farms with fields less than 1 ha in size are typically classified as being small.

Considering the subjectivity of definitions, here we strongly recommend that empirically collected data from the fields could be used as basis for distinguishing the SFSE scenario from large farms using big equipment. Farms $<1$ ha in size and using tractors, tractor-powered tillage/seeding implements, or harvesters with a rated power of less than $75 \mathrm{~kW}$ and working widths less than $2.5 \mathrm{~m}$ could be categorized as SFSE. This general distinction can empirically reflect the reasonability of the long history of both the farming conventions evolved and the adaptability of small machines to the smallholding farms. 


\section{Soil response to harvester traffic in SFSE scenario}

In general, soil water content at the time of rice harvesting was much higher than wheat harvesting (Table 2). In rice harvesting seasons soil water content in 100-150 mm depth was both lower than that in 0-50 and 50-100 mm soil layers, indicating the presence of a dense hardpan having poor water holding capacity in the third depth. The core sampling in the second season (wheat harvesting in 2017) also showed the presence of this layer. The statistically significant differences of soil physical properties (water content and bulk density) in 100-150 mm depth with respect to the above 2 layers agreed well with the findings of previous studies (Lennartz et al., 2009; Zhou et al., 2014). Lennartz et al. (2009), based on their large-scale field investigation, concluded that smallholding and paddy-based farmlands typically had a puddled layer at $110-170 \mathrm{~mm}$ in terraced and fragmentally managed landscapes. Puddling over long periods of time resulted in hardpans at shallow depths (Zhou et al., 2014), leading to a reduced water holding capacity. This can explain the reduced water content in the $100-150 \mathrm{~mm}$ soil layer.

Neither soil bulk density nor soil porosity in the paddy-based SFSE scenario changed significantly after harvester traffic, irrespective of either crop seasons or soil layers. This agreed well with the findings of Botta et al. (2006), who observed a small tractor traffic and found that soil bulk density responded insignificantly. Insensitivity of soil physical status to small harvester traffic indicated that current track design standard with a $20 \mathrm{kPa}$ contacting pressure threshold was effective for soil structure protection in paddy-based SFSE scenario. 
The inexpensive and easy to use penetrometer was commonly used in soil compaction studies

(Bennett et al., 2013). The new commercially available fine-layered digital cone penetrometer allowed us to identify how soil strength in each $25 \mathrm{~mm}$ layer responded to small harvester traffic. In all the 3 crop harvesting seasons, soil strength increased significantly within the top $150 \mathrm{~mm}$ soil layer (Fig.2), below which soil strength was much less affected. This clearly evidenced the protective effect of small harvesters on depth soil structures. The 4-depth soil sampling in 2017 wheat harvesting (Table 2) revealed unchanged soil physical parameters in-between and within the $3^{\text {rd }}$ and the $4^{\text {th }}$ depths. This result showed the benefit of illustrating the responses of each soil layer to harvester traffic using cone penetration data.

In the dryland cropping systems in northern China, Zhang et al. (2006) studied small tractor traffic and they found that a significant increase in cone penetration resistance only occurred in the 50 to $140 \mathrm{~mm}$ soil layer. Similarly, Botta et al. (2006) monitored small tractor traffic and observed that $150 \mathrm{~mm}$ was a threshold depth, below which penetration resistance was unaffected. Long-term soil cultivation using small machines generally results in a shallow hardpan as illustrated in Table 2 and Fig.2. Shallow pans can also occur on farms using big machines. Schjønning and Thomsen (2013) found that long-term shallow tillage to $100 \mathrm{~mm}$ on commercial farms may result in higher bulk density and increased cone penetration resistance, reduced pores and permeability, as well as critical conditions for root penetration. Therefore, soil management practices with low-power machines could be an important option for sustainable smallholder farming systems. 


\section{Rut depth under small harvester traffic}

Cropping systems apparently affected harvester-induced soil disturbance (Fig.3). Rut depth in wheat harvesting season was less than $50 \mathrm{~mm}$. In contrast, a wider distribution and higher value of rut depth was observed in rice harvesting. Considering the shallow soil depth managed/puddled (110-170 mm) (Lennartz et al., 2009), harvester-induced soil sinkage in the rice season was significantly large. Excessive soil sinkage also means a lateral movement of puddled soil, governed by plastic flow. Tagar et al. (2014) indicated that plastic flow was a major soil failure pattern of paddy soils.

Taken as an indicator of soil damage, rut depth $\mathrm{n}$ is often difficult to locate depending on surface conditions (McGarry et al., 2003). Inconsistent reports in soil sinkage observations was common. For instance, average rut depth induced by large harvester traffic was only $30 \mathrm{~mm}$ between lug marks (Radford et al., 2000). In contrast, Valera et al. (2012) observed 70-110 mm soil sinkage with one-pass tractor traffic of medium weights (2.77 Mg and 5.78 Mg). The inconsistent findings may imply that machine-induced soil disturbance could be governed by specificity of the attributes of a farming system. Trafficability of wet puddled soils was even worse when compared with dryland farming systems. Puddling for rice cultivation also destroyed soil structure (Zhou et al., 2014), leading to a poor strength and stability of the wet puddled layer, another potential cause for a low soil bearing capacity in paddy-based SFSE scenario. 
Management strategies for reduced soil compaction generally relied on increased soil organic carbon, crop rooting, reduced tire inflation pressure and controlled traffic farming (Hamza and Anderson, 2005; Batey, 2009). Our field survey observed additional farming practices in local which could be effective for improved soil compaction management. Use of light-weight machines, alternative cropping systems, a shift from paddy to dryland farming, and land consolidation facilitating the big machines working in large fields are promising options to ameliorate machine-induced soil disturbance. Small and/or irregular shaped fields not only decrease establishment efficiency (Bochtis et al., 2010; Gónzalez et al., 2007), but also affect harvester's fieldwork patterns, leading to decreased efficiency and increased compaction area ratio (Zhou et al., 2015; Bochtis and Vougioukas, 2008). In certain cases, even an introduction of improved headland turning pattern could potentially reduce traffic intensity and thereby soil damage (Bochtis and Vougioukas, 2008). Field size influences not only machinery selection (Mehta et al., 2011), but also field operational efficiency (Nguyen et al., 1996; Tan et al., 2010).

This investigation also highlighted that farmers' awareness of soil protection was generally poor. Harvester operators tended to drive randomly in the field (Fig.4), rather than following the recommended routing pattern as proposed by Bochtis and Vougioukas (2008) for minimized field traffic. In addition, small and simple harvesters were not as easy to steer as bigger harvesters. This meant that drivers of small harvesters had difficulty in aligning the cutter bar with the uncut crop. Also, when fields were flooded for the paddy, pre-existing traffic lanes could be visually destroyed. 
Crop boundaries amid fields shift from season to season, as the fragmented landscapes were managed by different farmers. Inconsistently managed fields and cropping systems posed a problem for uniform field operations.

Another major factor against effective soil compaction management in SFSE scenario was the numerous models of machines used with poor compatibility. Controlled traffic farming (CTF) requires systematic traffic patterns and compatibility between implements (Chamen et al., 2015). CTF needs fields with permanent wheel tracks (Chamen et al., 2006). Tullberg et al. (2007) highlighted a commercial system using a $3 \mathrm{~m}$ track widths and tires of $0.5 \mathrm{~m}$ section for the tractor, harvester and trailers, a working width of $9 \mathrm{~m}$ for the seeder and harvester and $27 \mathrm{~m}$ for the sprayer used in Australia. Chamen et al. (2015) stated that a $12 \mathrm{~m}$ CTF system had a minimum tracked area of about $13 \%$. Yet in the SFSE scenario, even if the CTF is implemented, a high compaction area ratio of $40 \%$ by the track would still render it unacceptable (Table 1 ).

\section{Preventive strategies to ameliorate soil disturbance in SFSE scenario}

The field survey also identified several management strategies to alleviate soil compaction. Drainage before rice harvesting (Fig.5a) is one important practice. Draining the field 10-20 days before grain harvesting allows the soil to regain a good bearing capacity. In rice-wheat rotating areas, alternative seasonal wetting and drying lead to shifts between anaerobic and aerobic soil conditions. Drainage speeds up the paddy-to-dryland shift. 
Another conservative approach was the use of 'ultra-narrow wheels' (Fig.5b). In theory, replacing tractor wheels with tracks increases tractive performance (Rasool and Raheman, 2018) and reduces soil compaction. This research indicated that even using tracked small harvesters, soil damage in paddy harvesting was still high. Mastura et al. (2011) indicated that paddy soil was basically compacted by machine traffic. Therefore the ultra-narrow wheels could be an important option for reduced size ratio of soil damage in paddy systems where soil compaction is unavoidable.

Floating chassis (Fig.5c) was the third management strategy found locally. In this system, one or more floating boards were used for supporting the machinery designed in light-weight. Although this approach together with puddling and transplanting do not belong to crop harvesting, mixed mechanized field operations done by different smallholders were overlain during our field survey in crop harvesting season. Also, all these approaches were intimately related to mechanized disturbance on the soil and thus worth mentioning here.

Puddling (Fig.5d) is a remedy approach for severely disturbed soil, done with a tractor and rotor puddling assembly before rice transplanting. Puddling not only recovers a leveled soil surface, but also creates a dense and impermeable pan layer that supports water ponding for paddy season, a key treatment minimizing water percolation losses and for higher water and nutrient using efficiency. Over centuries, soil cultivation and puddling have resulted in pans which reduced infiltration rates (Janssen and Lennartz, 2007). Improved soil micro-relief quality after puddling also minimized water usage in flooding periods necessitated by certain rice growing stages. 
Machinery traffic influence on soils could be site-specific in different SFSE scenarios. In drought agriculture, particularly resource-poor areas in sub-Saharan Africa, seeders attached to 2WT promote conservation in local agriculture (Johansen et al., 2012). In highly mechanized, smallholding and paddy-based farming systems, e.g. Japan, Korea and east China, machinery traffic damage on the soil could be severe. Most operations in paddy fields have to be performed while the soil is wet or saturated, thus the soils are particularly susceptible to compaction (Chamen et al., 2015). Mechanized field operation in wet soil is occasionally unavoidable, due mainly to short-term economic necessity (Radford et al., 2000). The combined effect of intensive mechanization, paddy production, humid climatic and land fragmentation threatens the sustainability of mechanized smallholder farming systems.

Soil structure and its functional properties vary in space and time (Strudley et al., 2008). Precision management of soil in mechanized SFSE scenario requires detailed knowledge on machine-induced soil disturbance. The knowledge of soil structural dynamics is essential for effective soil productivity and environmental services (Jirků et al., 2013). Small harvester-induced topsoil disturbance in paddy-based SFSE scenario yet protected subsoil. However, damage on soil micro-relief was unavoidable.

As flooded paddy farming systems require a well-leveled soil surface for water and nutrients conservation, a key management issue of such systems is a minimized disturbance on soil micro-relief. Sung and Jang (2006) monitored rut depth in Korean paddy soils. They found a 
dramatically changed soil profile within a single crop season induced by mechanized field operations

(i.e. plowing, rice transplanting, plant growth management and harvesting). Shoji et al. (2005)

investigated the soil profile within a 0.5 ha paddy field in Japan and observed as large as $100 \mathrm{~mm}$ of soil surface change. They also found that grain yield and protein content were negatively correlated with the intensity of soil profile disturbance. Traffic-induced soil disturbance or rut leads to considerable soil degradation (Horn et al., 2004; Naghdi et al. 2009). Ruts reduce soil pore space, injure and cut roots, obstruct natural flow paths, produce stagnant water pools, and initiate gulley formation and washouts along slopes (Carter et al. 2007; Blouin et al. 2005). However, interactions among soil compaction and crop growth, soil properties and seasonal weather conditions are complicated (Earl, 1997; Connolly, 1998; Radford et al., 2000). Soil disturbance induced by each mechanized field operations thus require detailed documentation in different SFSE scenarios.

\section{CONCLUSIONS}

A field survey toolbox parameterizing farming system's attributes can be applied to quantify how the crop seasons, soil physics, machinery specifications and farming practices may affect machine-induced soil disturbance.

Small, light-weight and tracked harvesters damaged soil micro-relief severely in paddy-based smallholder farming system. The severity of harvester-induced soil damage in paddy harvesting was higher than in wheat harvesting. 
Soil strength increased and soil porosity decreased after harvester traffic, but all these changes occurred within the topsoil layer, indicating satisfactory protective effect on the subsoil structures. However, soil micro-relief damage was unavoidable and thus improved management strategies for reduced soil compaction ratio and alleviated soil micro-relief disturbance are needed.

Extra outcomes from our field survey include locally established management strategies which were identified effective to ameliorate or rehabilitate harvester-induced soil disturbances, including pre-harvesting drainage, ultra-narrow wheels, floating chassis and puddling.

\section{Acknowledgments}

Financial support from Jiangsu Agriculture Science and Technology Innovation Fund (No.CX(17)1002 and CX(17)3030), the State Key Program of China (No.2016YFD0300900), the North Jiangsu Science and Technology Program (No.SZ-LYG2017008) and the Scientific Research Innovation Projects of Ordinary University Graduate Students in Jiangsu Province (No.KYXL16-1015) were acknowledged. The authors would like to thank the teacher's and supervisor's technical support. We are also grateful to the editor and anonymous reviewers for providing helpful suggestions to improve the quality of the present paper.

\section{REFERENCES}

Amiama, C., J. Bueno, and C.J. Álvarez. 2008. Influence of the physical parameters of fields and of crop yield on the effective field capacity of a self-propelled forage harvester. Biosyst. Eng. 100:198-205. doi:10.1016/j.biosystemseng.2008.03.004

This article is protected by copyright. All rights reserved. 
Batey, T. 2009. Soil compaction and soil management - a review. Soil Use Manage. 25:335-345. doi: 10.1111/j.1475-2743.2009.00236.x

Bennett, J.M., D.L. Antille, and S.R. Raine. 2013. Technological and integrated approaches for practical and rapid assessment of compaction in agricultural soils: a review. Energy Fuels 23:5179-5183. doi: 10.1021/ef900704h

Blouin, V.M., M.G. Schmidt, C.E. Bulmer, and M. Krzi. 2005. Mechanical disturbance impacts on soil properties and lodgepole pine growth in British Columbia's central interior. Can. J. Soil Sci. 85:681-691. doi: 10.4141/S04-077

Bochtis, D.D., C.G. Sørensena, and S.G. Vougioukas. 2010. Path planning for in-field navigation-aiding of service units. Comput. Electron. Agric. 74:80-90. doi:10.1016/j.compag. 2010.06.008

Bochtis, D.D., and S.G. Vougioukas. 2008. Minimising the non-working distance travelled by machines operating in a headland field pattern. Biosyst. Eng. 101:1-12. doi:10.1016/j. biosystemseng.2008.06.008

Botta, G.F., D. Jorajuria, H. Rosatto, and C. Ferrero. 2006. Light tractor traffic frequency on soil compaction in the Rolling Pampa region of Argentina. Soil Tillage Res. 86: 9-14. doi:10.1016/j.still.2005.01.014

Carter, E.A., W.M. Aust, and J.A. Burger. 2007. Soil strength response of select soil disturbance classes on a wet pine flat in South Carolina. For. Ecol. Manage. 247:131-139. doi:10.1016/j.foreco.2007.04.026

Chamen, W.C.T., C.J. Baker, K.E. Saxton, W. R. Ritchie, W.C.T. Chamen, et al., 2006. Controlled-traffic farming as a complementary practice to no-tillage. In: C.J. Baker and K.E. Saxton, editors, No-tillage seeding in conservation agriculture. Cromwell Press, Trowbridge, UK. p.236-256.

Chamen, W.C.T., A.P. Moxey, W. Towers, B. Balana, and P.D. Hallett. 2015. Mitigating arable soil compaction: A review and analysis of available cost and benefit data. Soil Tillage Res. 146:10-25. doi:10.1016/j.still.2014.09.011

Chung, S.O., I.K. Jung, J.H. Sung, K.A. Sudduth, and S.T. Drummond. 2008. Analysis of spatial variability in a Korean paddy field using media polish detrending. Journal of Biosystems Engineering 33: 362-369. doi: 10.5307/JBE.2008.33.5.362

This article is protected by copyright. All rights reserved. 
Connolly, R.D. 1998. Modelling effects of soil structure on the water balance of soil-crop systems: a review. Soil Tillage Res. 48:1-19. doi: 10.1016/s0167-1987(98)00128-7

Dash, R.C., and N.P.S. Sirohi. 2008. A computer model to select optimum size of farm power and machinery for paddy-wheat crop rotation in northern India. CIGR Journal. 10:1-11

Ding, Q.S., C.S. Dong, Y.N. Li, W. Qiu, J.I. Xue, et al. 2016. Digital image processing of mass-size distribution of soil structures in plough layer. (In Chinese, with English abstract.) Trans. CSAE 32: 134-140.

Earl, R. 1997. Prediction of trafficability and workability from soil moisture deficit. Soil Tillage Res. 40: 155-168. doi: 10.1016/s0167-1987(96)01072-0

Esengun, K., O. Gündüz, and G. Erdal. 2007. Input-output energy analysis in dry apricot production of Turkey. Energy Convers. Manage. 48:592-598. doi:10.1016/j.enconman. 2006.06. 006

Falco, S.D., I. Penov, A. Aleksiev, and T.M.V. Rensberg. 2010. Agrobiodiversity, farm profits and land fragmentation: Evidence from Bulgaria. Land Use Policy 27:763-771. doi:10.1016/ j.landusepol. 2009. 10.007

Gónzalez, X.P., M.F. Marey, and C.J. Álvarez. 2007. Evaluation of productive rural land patterns with joint regard to the size, shape and dispersion of plots. Agric. Syst. 92, 52-62. doi:10.1016/j.agsy.2006.02.008

Gregory, A.S., C.W. Watts, W.R. Whalley, H.L. Kuan, B.S. Griffiths, et al. 2007. Physical resilience of soil to field compaction and the interactions with plant growth and microbial community structure. Eur. J. Soil Sci. 58:1221-1232. doi:10.1111/j.1365-2389.2007.00956.x

Grossman, R.B., and T.G. Reinsch. 2002. Bulk density and linear extensibility. In: J.H. Dane and G.C. Topp, editors, Methods of soil analysis. Part 4. Agron. Monogr. 5. SSSA, Madison, WI. p. 201-225.

Gysi M., V. Maeder, and P. Weisskopf. 2001. Pressure distribution underneath tires of agricultural vehicles. Trans. ASAE. 44 (6), 1385-1389. doi:10.13031/2013.7001

Håkansson, I., and R.C. Reeder. 1994. Subsoil compaction by vehicles with high axle load-extent, persistence and crop response. Soil Tillage Res. 29:277-304. doi: 10.1016/0167- 1987 (94)90065-5 
Hamza, M.A., and W.K. Anderson. 2005. Soil compaction in cropping systems: A review of the nature, causes and possible solutions. Soil Tillage Res. 82:121-145. doi: 10.1016/j. still.2004.08.009

Haque, M.E., R.W. Bell, M.A. Islam, and M.A. Rahman. 2016. Minimum tillage unpuddled transplanting: An alternative crop establishment strategy for rice in conservation agriculture cropping systems. Field Crops Res. 185:31-39. doi: 10.1016/j.fcr.2015.10.018

Horn, R., J. Vossbrink, and S. Becker. 2004. Modern forestry vehicles and their impacts on soil physical properties. Soil Tillage Res. 79:207-219. doi: 10.1016/j.still.2004.07.009

Hülsbergen, K.J., B. Feil, and W. Diepenbrock. 2002. Rates of nitrogen application required to achieve maximum energy efficiency for various crops: results of a long-term experiment. Field Crops Res. 77:61-76. doi: 10.1016/S0378-4290(02)00050-3

Janssen, M., and B. Lennartz. 2007. Horizontal and vertical water and solute fluxes in paddy rice fields. Soil Tillage Res. 94:133-141. doi: 10.1016/j.still.2006.07.010

Jirků, V., R. Kodešová, A. Nikodem, M. Mühlhanselová, and A. Žigová. 2013. Temporal variability of structure and hydraulic properties of topsoil of three soil types. Geoderma 204-205:43-58. doi:10.1016/j.geoderma.2013.03.024

Johansen, C., M.E. Haque, R.W. Bell, C. Thierfelder, and R.J. Esdaile. 2012. Conservation agriculture for small holder rainfed farming: Opportunities and constraints of new mechanized seeding systems. Field Crops Res. 132:18-32. doi:10.1016/j.fcr.2011.11.026

Latruffe, L., and L. Piet. 2014. Does land fragmentation affect farm performance? A case study from Brittany, France. Agric. Syst. 129:68-80. doi:10.1016/j.agsy.2014.05.005

Lennartz, B., R. Horn, R. Duttmann, H.H. Gerke, R. Tippkötter, et al. 2009. Ecological safe management of terraced rice paddy landscapes. Soil Tillage Res. 102:179-192. doi:10.1016/j. still.2008.07.010

Lipiec, J., and R. Hatano. 2003. Quantification of compaction effects on soil physical properties and crop growth. Geoderma 116:107-136. doi:10.1016/S0016-7061(03)00097-1 
Mastura, M., M.S.M. Amin, and W. Aimrun. 2011. Characterization of paddy soil compaction based on soil apparent electrical conductivity zones. Afri. J. Agric. Res. 6:2506-2515. doi:10.1021/jf2016557

McGarry, D., and G. Sharp. 2003. A rapid, immediate, farmer-usable method of assessing soil structure condition to support conservation agriculture. In: L. Garcia-Torres et al., editors, Conservation Agriculture. Springer, Dordrecht. p. 375-380.

Mehta, C.R., K. Singh, and M.M. Selvan. 2011. A decision support system for selection of tractorimplement system used on Indian farms. J. Terramechanics 48:65-73. doi:10.1016/j. jterra.2010.05.002

Mousavi-Avval, S.H., A. Mohammadi, S. Rafiee, and A. Tabatabaeefar. 2012. Assessing the technical efficiency of energy use in different barberry production systems. J. Clean. Prod. 27:126-132.doi: 10.1016/j.jclepro.2012.01.014

Muazu, A., A. Yahya, W.I.W. Ishak, and S. Khairunniza-Bejo. 2015. Energy audit for sustainable wetland paddy cultivation in Malaysia. Energy 87:182-191. doi:10.1016/j.energy. 2015.04.066

Naghdi, R., I. Bagheri, M. Lotfalian, and B. Setodeh. 2009. Rutting and soil displacement caused by 450C Timber Jack wheeled skidder (Asalem forest northern Iran). J. Forest Sci. 55:177-183. doi:10.17221/102/2008-JFS

Nguyen, T., E. Cheng, and C. Findlay. 1996. Land fragmentation and farm productivity in China in the 1990s. China Econ. Rev. 7:169-180. doi:10.1016/S1043-951X(96)90007-3

Nilsson D., H. Rosenqvist, and S.Bernesson. 2014. Time demand for machine operations in small fields - a simulation study. Techincal report doi:10.13140/RG.2.1.4348.6246.

Oksanen, T. 2013. Shape-describing indices for agricultural field plots and their relationship to operational efficiency. Comput. Electron. Agric. 98:252-259. doi:10.1016/j.compag. 2013. 08.014

Radford, B.J., B.J. Bridge, R.J. Davis, D. Mcgarry, U.P. Pillai, et al. 2000. Changes in the properties of a Vertisol and responses of wheat after compaction with harvester traffic. Soil Tillage Res. 54:155-170. doi:10.1016/s0167-1987(00)00091-x

Rasool, S., and H. Raheman. 2018. Improving the tractive performance of walking tractors using rubber tracks. Biosyst. Eng. 167:51-62. doi:10.1016/j.biosystemseng.2017.12.013 
Schjønning, P., and I.K. Thomsen. 2013. Shallow tillage effects on soil properties for temperate-region hard-setting soils. Soil Tillage Res. 132:12-20. doi:10.1016/j. still. 2013. 04.006

Shoji, K., T. Kawamura, H. Horio, K. Nakayama, and N. Kobayashi. 2005. Variability of micro-elevation, yield, and protein content within a transplanted paddy field. Precis. Agric. 6:73-86. doi:10.1007/ s11119-004-0685-9

Sims B., and J. Kienzle. 2017. Sustainable agricultural mechanization for smallholders: what is it and how can we implement it? Agriculture 7:1-21. doi:10.3390/agriculture7060050.

Sims, B.G., P. Hobbs, and R. Gupta. 2009. Policies and institutions to promote the development and commercial manufacture of conservation agriculture equipment. The 4th World Congress on Conservation Agriculture, 4-7 February, New Delhi, pp. 308-328.

Søgaard, H.T., and C.G. Sørensen. 2004. A model for optimal selection of machinery sizes within the farm machinery system. Biosyst. Eng. 89:13-28. doi:10.1016/j.biosystemseng. 2004.05.004

Strudley, M.W., T.R. Green, and II.J.C. Ascough. 2008. Tillage effects on soil hydraulic properties in space and time: State of the science. Soil Tillage Res. 99:4-48. doi:10.1016/j. still.2008.01.007

Sung, J.H., and S.W. Jang. 2006. Variation Analysis of Elevation within a Rice Paddy Field. (In Korean, with English abstract.) Korean Journal of Soil Science \& Fertilizer 31:188-193.

Tagar, A.A., C.Y. Ji, Q.S. Ding, J. Adamowski, F.A. Chandio, et al. 2014. Soil failure patterns and draft as influenced by consistency limits: An evaluation of the remolded soil cutting test. Soil Tillage Res.137:58-66. doi:10.1016/j.still.2013.12.001

Tan, S., N. Heerink, G. Kruseman, and F. Qu. 2008. Do fragmented landholdings have higher production costs? Evidence from rice farmers in Northeastern Jiangxi province, P.R. China. China Econ. Rev. 19:347-358. doi:10.1016/j.chieco.2007.07.001

Tan, S., N. Heerink, A. Kuyvenhoven, and F. Qu. 2010. Impact of land fragmentation on rice producers' technical efficiency in South-East China. NJAS-Wageningen J. Life Sc. 57:117-123. doi:10.1016/ j.njas. 2010.02.001

Tullberg, J.N., D.F. Yule, and D. McGarry. 2007. Controlled traffic farming-From research to adoption in Australia. Soil Tillage Res. 97:272-281. doi: 10.1016/j.still.2007.09.007

This article is protected by copyright. All rights reserved. 
Valera, D.L., J. Gil, and J. Agüera. 2012. Design of a new sensor for determination of the effects of tractor field usage in southern spain: soil sinkage and alterations in the cone index and dry bulk density. Sensors 12:13480-13490. doi:10.3390/s121013480

Wang, H. 2018. Study on soil mechanical compaction by harvesting machinery under rice-wheat rotation. M.D. diss., Nanjing Agricultural Univ., Nanjing.

Williams, D. M., H. Blanco-Canqui, C. A. Francis, and T. D. Galusha. 2017. Organic Farming and Soil Physical Properties: An Assessment after 40 Years. Agron. J. 109:600-609. doi:10.2134/agronj2016.06.0372

Zhang, X.Y., R.M. Cruse, Y.Y. Sui, and Z. Jhao. 2006. Soil compaction induced by small tractor traffic in northeast china. Soil Sci. Soc. Am. J. 70:613-619. doi:10.2136/ sssaj2005.0121

Zhang, Z., A.D. Mchugh, H. Li, S. Ma, Q. Wang, et al. 2017. Global overview of research and development of crop residue management machinery. App. Eng. Agri. 33:329-344. doi:10.13031/aea.12167

Zhou, H., H. Fang, C. Hu, S. J. Mooney, W. Dong, and X. Peng. 2017. Inorganic Fertilization Effects on the Structure of a Calcareous Silt Loam Soil. Agron. J. 109:2871-2880. doi:10.2134/agronj2016.10.0590

Zhou, G., K. Hu, X. Zhao, J. Wang, H. Liang, et al. 2015. Laboratory investigation on tensile strength characteristics of warm frozen soils. Cold Reg. Sci. Technol. 113:81-90. doi:10.1016/j.coldregions. 2015. 02.003

Zhou, W., T. Lv, Y. Chen, A.P. Westby, and W. Ren. 2014. Soil Physicochemical and Biological Properties of Paddy-Upland Rotation: A Review. The Scientific World Journal 2014:1-8.doi: $10.1155 / 2014 / 856352$

Zink, A., H. Fleige, and R. Horn. 2011. Verification of harmful subsoil compaction in loess soils. Soil Tillage Res. 114:127-134.doi: 10.1016/j.still.2011.04.004 
Fig.1. Comparison of field size between smallholder farms (a) and large commercial farms (b).

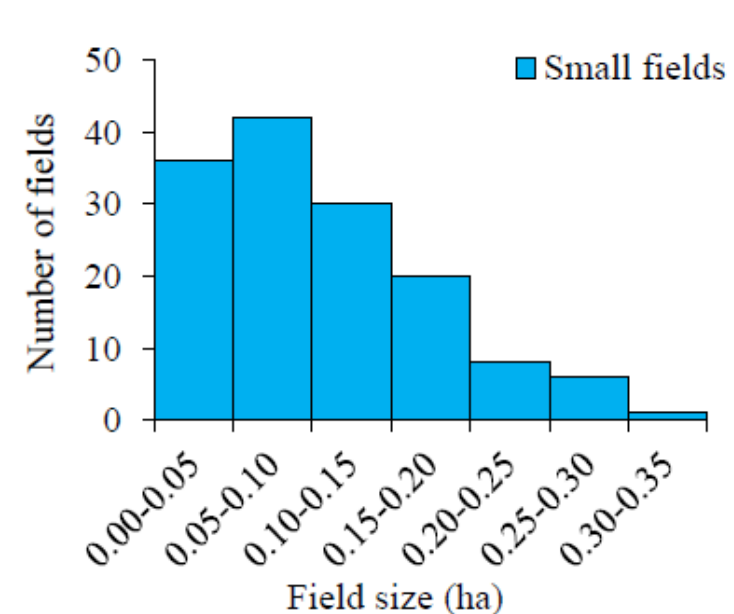

a

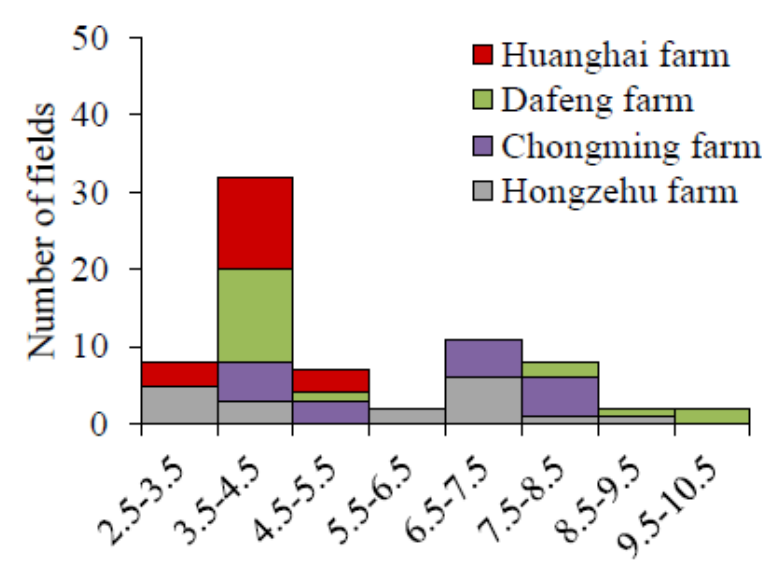

Field size (ha)

$\mathrm{b}$

Fig.2. Soil strength changes with soil depth from 0 to $225 \mathrm{~mm}$ (averaged for all fields).

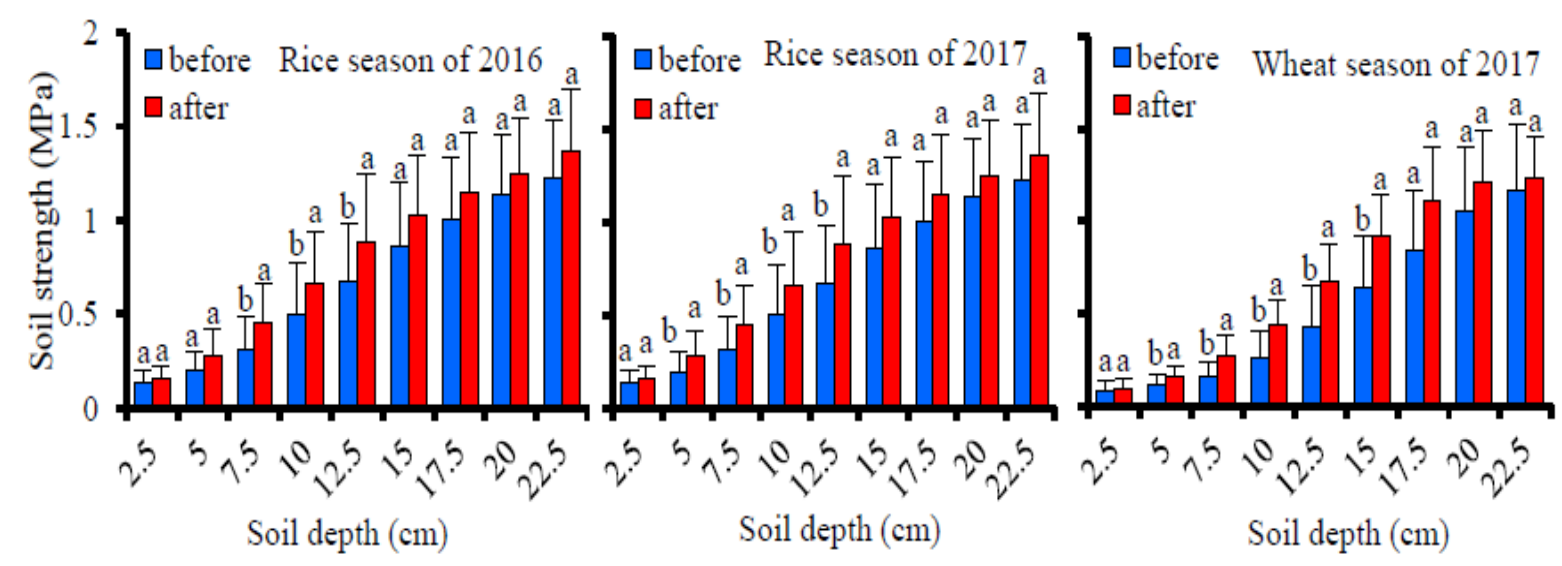

This article is protected by copyright. All rights reserved. 
Fig.3. Comparison of soil sinkage between rice and wheat harvesting.

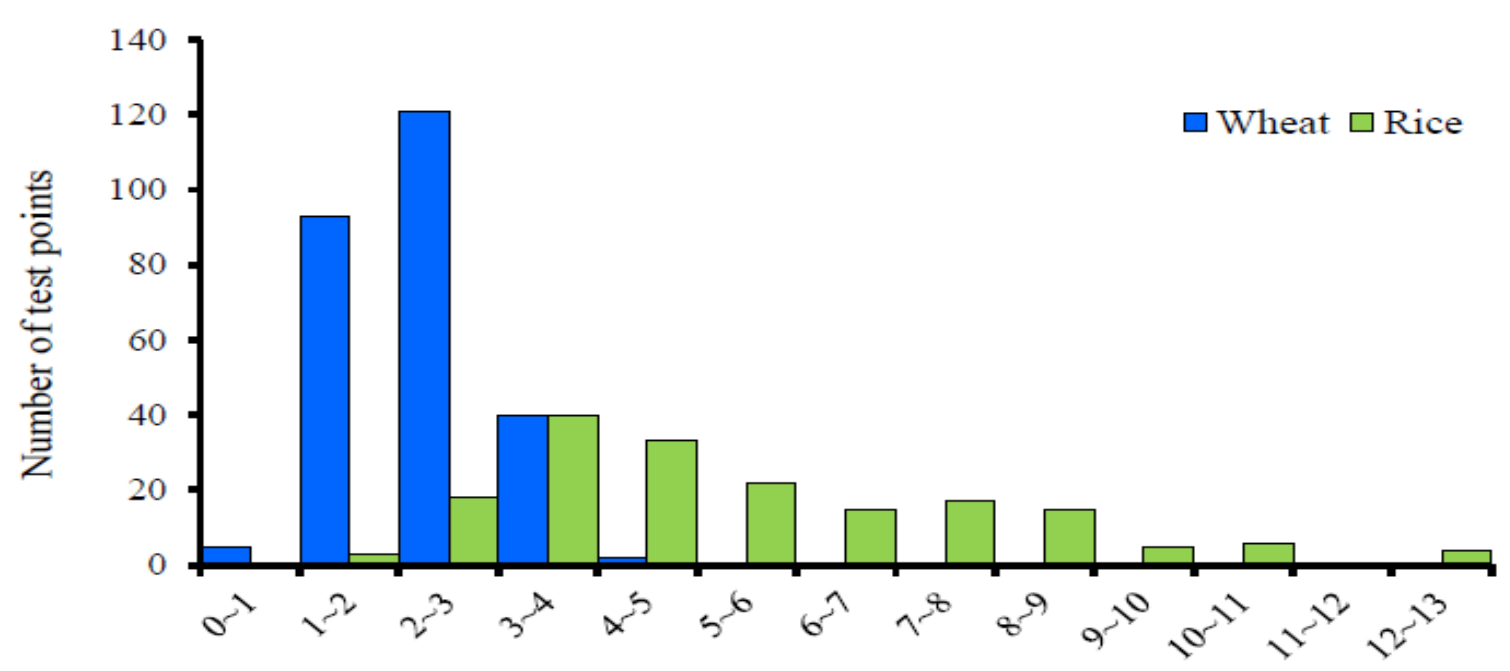

Sinkage $(\mathrm{cm})$

Fig.4. In a humid region, crop harvesting is generally done regardless of optimum field trafficability (a). Random traffic patterns observed in a headland (b). Damage of soil micro-relief within the field (c).

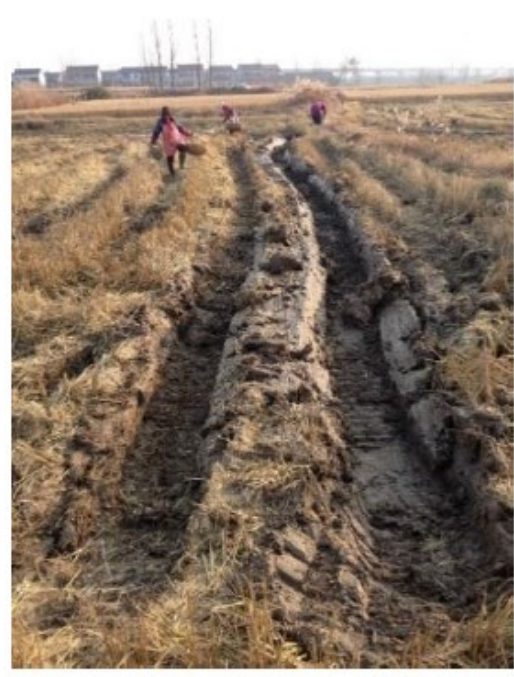

a

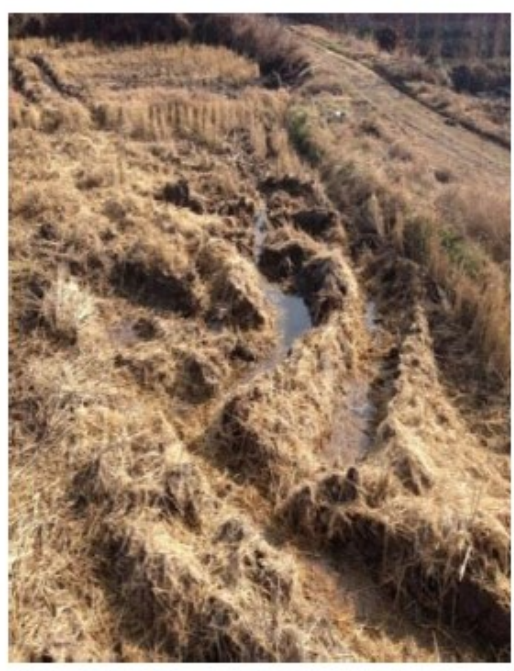

b

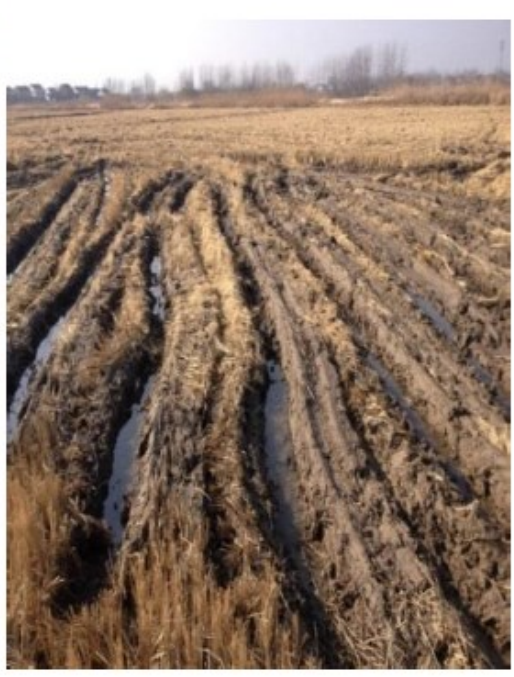

c 
Fig.5. Management strategies to alleviate soil compaction in paddy-based

SFSE scenario. (a) Drainage before harvesting, (b) Ultra-narrow wheels, (c)

Floating chassis, (d) Puddling

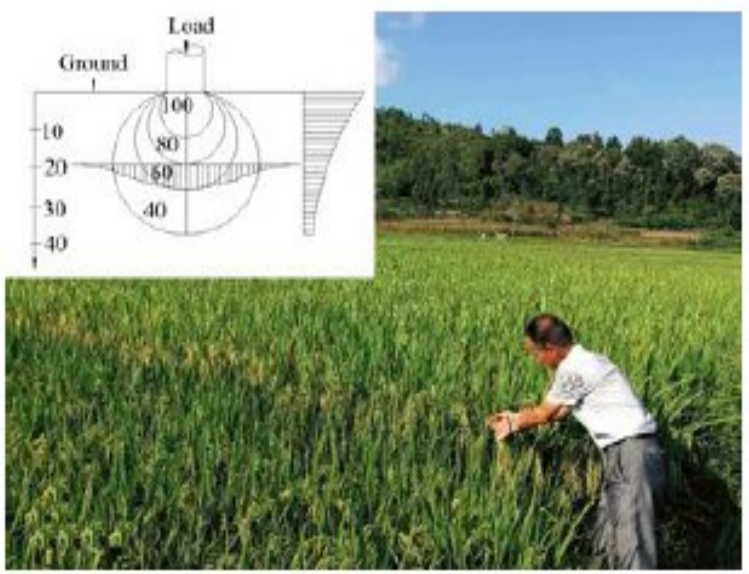

a

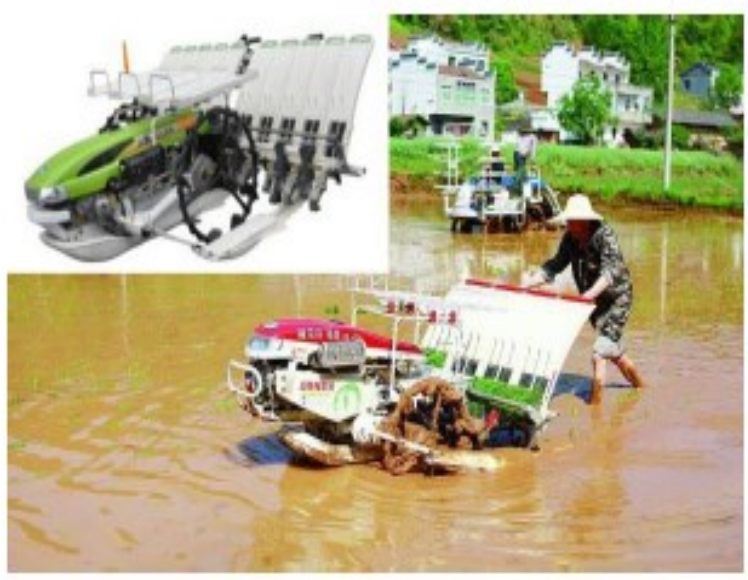

c

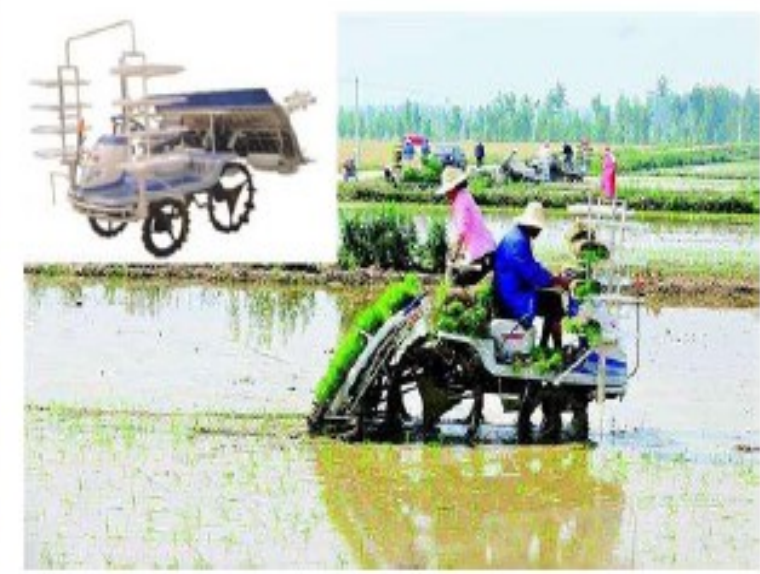

b

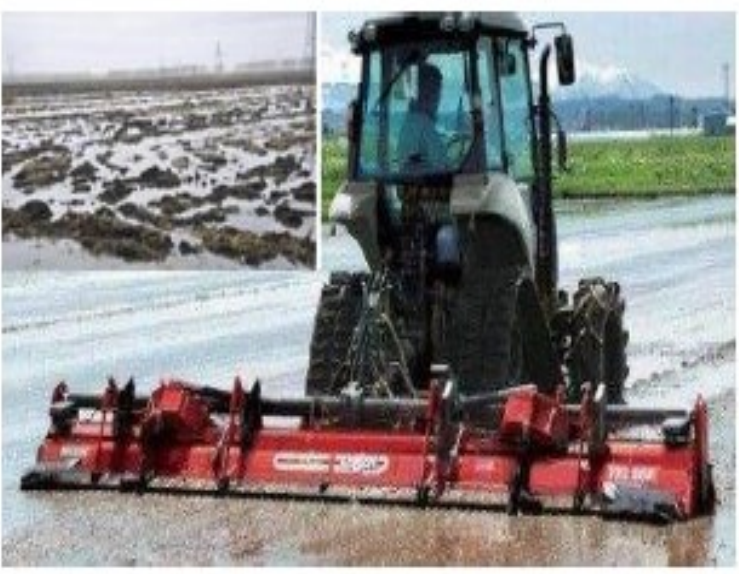

d

This article is protected by copyright. All rights reserved. 


\section{Table 1. A comparison between the harvesters used in small and large}

commercial farms for rice and wheat harvesting.

\begin{tabular}{|c|c|c|c|c|c|c|c|}
\hline \multirow[t]{3}{*}{ Model } & \multicolumn{4}{|c|}{ Small harvesters } & \multicolumn{3}{|c|}{ Large harvesters } \\
\hline & Kubota & World & RG50 4LZ-5G & YH880 & John Deere & Mushen & Case 4077 \\
\hline & PRO688Q & $4 \mathrm{LZ}-4.0 \mathrm{~A}$ & & & C120 & $4 L Z-8$ & \\
\hline \multirow[t]{3}{*}{ Producer } & Kubota Agri. & World Agri. & Lovol Heavy & Yanmar & John Deere & Xinjiang & Case New \\
\hline & Mach. Co., & Mach. Lt. & Industry Co., & Agri. Mach. & Co., Ltd. & Mach. Res. & Holland \\
\hline & Ltd. & & Ltd. & Co., Ltd. & \multicolumn{3}{|c|}{ Inst. Co., Ltd. } \\
\hline Power, kW & 49.2 & 65 & 74 & 64.2 & $121 / 165$ & 140 & 180 \\
\hline Weight, Mg & 2.78 & 2.5 & 3.2 & 3.5 & N.A. & 8.5 & 10.432 \\
\hline Contact & 20.3 & 54.4 & 69.7 & 19.6 & N.A. & N.A. & N.A. \\
\hline \multicolumn{8}{|l|}{ Pressure, kPa } \\
\hline $\begin{array}{c}\text { Work Width, } \\
\text { mm }\end{array}$ & 2000 & 2200 & 2000 & 2200 & 4570 & 4570 & 5180 \\
\hline Compaction & 0.40 & 0.41 & 0.50 & 0.45 & N.A. & 0.20 & N.A. \\
\hline Area Ratio & & & & & & & \\
\hline
\end{tabular}

† N.A.: not available.

Table 2. Soil physical properties before and after harvester traffic at various depths in 3 crop harvesting seasons (average of all fields).

\begin{tabular}{|c|c|c|c|c|c|c|}
\hline & \multirow[t]{2}{*}{ Soil layers } & \multirow{2}{*}{$\begin{array}{c}\text { Soil water } \\
\text { content }\end{array}$} & \multicolumn{2}{|c|}{ Soil bulk density } & \multicolumn{2}{|c|}{ Soil porosity } \\
\hline & & & before & after & before & after \\
\hline & $\mathrm{mm}$ & $\%$ & \multicolumn{2}{|c|}{$\mathrm{g} \mathrm{cm}^{-3}$} & \multicolumn{2}{|c|}{$\%$} \\
\hline 2017 Rice & $0-50$ & $41.17 a$ & $1.16 c$ & $1.18 c$ & $56.41 a$ & $55.49 a$ \\
\hline
\end{tabular}




\begin{tabular}{|c|c|c|c|c|c|c|}
\hline & $50-100$ & $40.69 a$ & $1.24 b c$ & $1.31 b$ & $53.05 a b$ & $50.66 b$ \\
\hline & $100-150$ & $33.43 b$ & $1.35 a b$ & $1.45 a$ & $49.23 b c$ & $45.41 \mathrm{c}$ \\
\hline \multirow[t]{4}{*}{2017 Wheat } & $0-50$ & $16.11 a$ & $1.05 c$ & $1.20 \mathrm{bc}$ & $60.33 a$ & 54.78ab \\
\hline & $50-100$ & $17.78 a$ & $1.13 c$ & $1.24 b$ & 57.33ab & $53.22 b$ \\
\hline & $100-150$ & $15.80 \mathrm{a}$ & $1.42 \mathrm{a}$ & $1.41 \mathrm{a}$ & $46.30 c$ & $47.02 \mathrm{c}$ \\
\hline & $150-200$ & $18.17 a$ & $1.49 a$ & $1.43 a$ & $44.00 c$ & $46.00 c$ \\
\hline \multirow[t]{3}{*}{2016 Rice } & $0-50$ & $31.73 a$ & $1.20 \mathrm{~d}$ & $1.26 \mathrm{c}$ & $54.77 a$ & 52.36ab \\
\hline & $50-100$ & $30.21 a b$ & $1.31 b c$ & $1.39 a$ & $50.39 b$ & $47.71 b c$ \\
\hline & $100-150$ & $28.56 b$ & $1.43 a$ & $1.45 a$ & $46.09 c$ & $45.12 c$ \\
\hline
\end{tabular}

+ Means followed by the same letter are not statistically different at $p=0.05$.

This article is protected by copyright. All rights reserved. 